\title{
XXIII. Of the state of vapour subsisting in the atmosphere
}

\author{
Richard Kirwan Esq. LL.D. F.R.S. P.R.I.A.
}

To cite this article: Richard Kirwan Esq. LL.D. F.R.S. P.R.I.A. (1802) XXIII. Of the state of vapour subsisting in the atmosphere, Philosophical Magazine Series 1, 14:54, 143-148, DOI: 10.1080/14786440208676175

To link to this article: http://dx.doi.org/10.1080/14786440208676175

曲 Published online: 18 May 2009.

Submit your article to this journal $\sqsubset \pi$

ЏII Article views: 2

Q View related articles $\square$ 


\section{$\left[\begin{array}{ll}143 & ]\end{array}\right.$}

XXIII. Of the State of Vapour ficlyjting in the Atmo/phere. By Richand KinWan, Ejq. LL.D. F.R.S. and P.R.I.A.*

$\mathrm{V}$

APOUR or moifture in the atmofphere may rubfift in denfe air, or in air highly rarefied: that it is found in the former is well known, and that it may fubfift in the latter appears by the obfervations of Bouguer; for he faw clouds three or four hundred toiles above Chiromboracho, and confequently at the height of twenty-two thoufand five hundred and twenty-eight Englifh feet, or 4.3 miles over the level of the fea; a height at which in the temperature of $32^{\circ}$ a barometer would ftand at 12.7 inches. At fuch heights, and at much inferior, fince evaporation proceeds much more quickly, it is not to be fuppofed that all the vapour fo rapidly produced is diflolved in the ambient air, but part rifes in combined, as it does under an exhaufted or half-exhanted receiver, and in this cafe Mr. De Lue's fyltem is admifible. This emilfion of pure vapour feems to begin at heights at which the denfity of the air is 25 , (that is, at heights at which the barometer would ftand at twenty-five inches, and thus I fhall in future exprefs the various denfities of air, at leaft it is very confiderable where the denfity is twenty. This leads me to treat of the properties and fate of pure invifible vapour, namely, its fpecific beat, elafticity, and fpecific gravity.

The immortal Doctor Black, the father of all difcoveries of this kind, informed me that the vapour of water, boiling at $212^{\circ}$, that is, at $180^{\circ}$ above the freezing point, and pofferfing the fame fenfible heat as the water, contains nine hundred and forty times more latent heat than an equal weight of water does heated to $212^{\circ}$, or $5^{\circ} 222$ times more latent heat than it does of fenfible heat, counting from the freezing point, for $180 \times 5.222=940$ nearly. In this cale the preffure or denfity of the atmofphere is thirty, the barometer fanding at the height of thirty inches; and with Doctor Black's account the experiments of Mr. Schmidt of Gieflen very nearly agree; for according to him the latent heat of the vapon of water, barometer 29.84 inches, and the heat $212^{\circ}$, is 5.33 times greater than its fenfible heat above the freezing point: now $180 \times 5.33=959.4 \uparrow$. The diffarence or excels in his experiment proceeds from the prefiure of the at-

"From his paper intitled, "Of the Variatioas of the Atmolphere," Dub in, 1802 .

t Gren's Phyfical Jouraal, iv. p.3rs. 
mofphere being fomewhat lower, as Mr. Walt's cxperiments prove.

$\mathrm{Mr}$. Watt difcovered that the latent heat of fteam diminifhed in proportion as its fenfible heat increafed, Phil. Tranf. I784, p. 335. Now the fenfible heat of fteam exceeds $180^{\circ}$ above the freezing point when the barometer ftands above thirty inches, and lefs than $180^{\circ}$ when the barometer ftand 3 lower than thirty inches, as Mr. De Luc firft difcovered, and may be feen in Sir George Schuckburgh's and Mr. De Luc's tables, Phil. Tranf. 1779, p. 375. From thefe I have deduced the following table:

\begin{tabular}{|c|c|}
\hline \multicolumn{2}{|c|}{$\begin{array}{l}\text { Hcat of boiling } \\
\text { warer. }\end{array}$} \\
\hline Bar. & Heat. \\
\hline 30 & $212^{\circ}$ \\
\hline 29 & 210.28 \\
\hline 28 & $208 \cdot 52$ \\
\hline 27 & $206 \cdot 73$ \\
\hline 26 & $204^{\circ} 9^{\prime}$ \\
\hline 25 & 203.06 \\
\hline 24 & $201 \cdot 18$ \\
\hline 2.3 & $199^{\circ} 27$ \\
\hline 22 & $197 \cdot 33$ \\
\hline $2 I$ & $195^{\circ} 3^{6}$ \\
\hline 20 & 193.36 \\
\hline 19 & 191.06 \\
\hline 18 & 188.46 \\
\hline 17 & 185.56 \\
\hline 16 & 18436 \\
\hline 15 & 180.86 \\
\hline 14 & $176 \%$; \\
\hline
\end{tabular}

The accuracy of this table even in the lower part of the fcale is fufficiently apparent by the refult of the experiments of Sauffure on ebullition on Mount Blanc; for on that enormous mountain, the barometer ftanding at 16 French inches or 17.05 Englifh, he found water to boil at the heat of $68.993^{\circ}$ of Reaumur, a degree which on Geneva thermometers is equal to $1855^{\circ}$ Englih.-Hence we fee that diftillation may be more advantageounly effected on mountains than on plains, and at low barometrical heights than at the greater, yet within certain limits; for, at heights that furpafs 8 or 10 thoufand feet, the fuel, by reafon of the rarity of the air, is more nowly confumed. Hence alfo, from the knowledge of the degree of the heat of ebullition to two or more decimal places, the ftate of the barometer above or below $212^{\circ}$ may be inferred to one or more decimal places. The reafon of this rapid diminution of the heat of ebulition berefiftance, from the which which then is very fenfible: but as the cold continually produced by evaporation is then alfo very confiderable, the time neceffary to procure ebullition is longer, as Sauffure remarked on Mount Blanc. Vol. vii. in $8 v 0, \S 2011, \mathrm{p} .328$. He found the heat of ebullition barometer 16 to be 68.993 degrees, or in Englifh meafures barometer $17.05 .185^{\circ} 5^{\circ}$ of Fahr. (counting one of Reaumur at Geneva $=2: 225$ of Fahr.)

Hence fince, according to Mr. Watt, the fenfible heats of the vapours of boiling water at different barometrical heights are as the barometrical heights reciprocally, and the fpecific 
heats of the vapours of water boiling are as the fenfible heats reciprocally, it being known, that the fpecific heat of the vapour of water heated to 180 degrees above the freezing point is 940. The fpecific or latent heat of the vapour of boiling water, whofe fenfible heat is known, (and it may be known by the barometrical height as fhown in the above table and the notes) may alfo be difcovered.

Thus the fenfible heat of the vapour of boiling water barometer $3 \circ$ being $180^{\circ}$ above the freezing point $\left(212^{\circ}-32^{\circ}=\right.$ $180^{\circ}$ ) and the fpecific or latent heat of vapour, whofe fenfible heat is $208.5^{\circ}$ (that is $176^{\circ} 5^{6}$ above $32^{\circ}$ ) as it is when the barometer ftands at 28 inches, is $95^{\circ}$ for $\because 176.56 .180:$ : $940.95^{*}$.

As pure invifible vapour does not in my opinion (of which I have already ftated the grounds) exi(t in the atmofphere when its denfity is higher than 25, as it is in moft of the inhabited parts of the globe, but is always in this cafe united to air, an inquiry into its latent heat at different temperatures below ebullition were fuperfirous. But as it does exift in air whofe denfity is 25 or lefs, fince it is found in air whofe denfity is 12.5 , it becomes neceffary to examine its latent heat in fuch cafes, in all temperatures inferior to that of ebullition. Now, by analogy, I apprehend this latent heat in all inferior temperatures may thus be determined.

As the fenfable heat of ebullition, when the barometer is at 25 or below 25 , is to the latent heat of the vapour at ebullition, fo is the fenfible heat of water heated to any inferior degree above $32^{\circ}$ to the latent heat of its vapour, multiplied by 5.222 . Thus the fenfible heat of water in ebullition barometer 25 being $171^{\circ} 4^{\circ}\left(=2034^{\circ}-32^{\circ}\right)$ its fpecific heat is $987\left(=\frac{169206}{1714}\right)$ the latent heat of the vapour of water at $22^{\circ}$ above congelation (that is $52^{\circ}$ on Falur. fcale) is 657 for $\div 1714^{\circ} 987:: 22^{\circ}$. $1: 6 \times 5.22=657$. The latent beat of vapour in fuch cafes cannot be deternined by experiment, on account of the admixture of atmofpheric air: we muft therefore refort to analogy, which in this cafe is perfect.

The latent heat of pure vapour at greater heights is more confiderable: thits at heights, at which the barometer ftands at 20 inches, the latent heat of vapour whofe temperature is $22^{\circ}$ above $32^{\circ}$, a in the laft cafe, is 730 ; for the heat of ebullition is $193^{\circ}$, per table, $=162.8^{\circ}$, above $32^{\circ}$ : and the latent heat whthe vapour at ebullition is ro39. Now $\div$ $162 \cdot 8.1039^{\circ} 22.140$ and $140 \times 5.22=730$.

* Hence 16920 , the produet of $150^{\circ} \times 940$, is the common dividend of all fentible hidats. $6 e^{\circ}$ ow $180^{\circ}$, when che lueent hear us the vapour is fought at haramcrerical onghts below 30 inches.

VoL, XIV. No, 34 . 
As air is cooled by the reception of moifture diffolved in it, we muft infer that its capacity for containing heat is increafed, and hence moift air is more difficultly heated or cooled than dry air of the fame temperature. (Fior the cold proceeds from the ablorption and not from the expulfion of caloric.)

The elafticity or expanfive force of pure vapour has been examined at every fifth degree of Reaumur above 0 to $110^{\circ}$, by Mr. Betanconrt, and may be feen in an excellent work of Prouy's, bis Arcbitedure Hydraulique: he has by a mot ingenious calculation interpolated the expanfions anfwering to the intermediate degrees. But Mr. Schmidt feems to have determined this expanfive force ftill more exactly than Betancourt. Hence I here infert this table, adding Fahrenheit's for Reaumur's degrees, and diftinguifhing the expanfions interpolated by calculation from thofe actually obferved by $\boldsymbol{I}$. The forces are meafured by the elevation of a mercurial coJumn in inches and hundreds of a French inch*.

\begin{tabular}{|c|c|c|c|c|c|}
\hline Reaum. & Fahren. & $\begin{array}{c}\text { Expanfive } \\
\text { louce. }\end{array}$ & Reaum. & Fehren. & $\begin{array}{c}\text { Expanfive } \\
\text { Force. }\end{array}$ \\
\hline I & $34^{\circ} 25^{\circ}$ & $.01 I$ & $2 \mathrm{I}$ & $79^{\circ} 25^{\circ}$ & I.OI $I$ \\
\hline 2 & $36 \cdot 5$ & $.03 I$ & 22 & $8 \mathrm{I} \cdot 5$ & $I^{\prime} O I$ \\
\hline 3 & $3^{8} \cdot 75$ & $.05 I$ & 23 & $83 \cdot 75$ & $1 \cdot 19 I$ \\
\hline 4 & $4 I^{\circ}$ & $.07 I$ & 24 & 86. & $I \cdot 29 I$ \\
\hline 5 & $43 \cdot-5$ & - I I & 25 & $88 \cdot 25$ & 130 \\
\hline 6 & 455 & 15 & 26 & 90.5 & $1 \cdot 38 I$ \\
\hline 7 & $47 \cdot 75$ & $.16 I$ & 27 & 92.75 & $I \cdot 42$ \\
\hline 8 & $50^{\circ}$ & $.20 I$ & 28 & $95^{\circ}$ & $\mathrm{I} .60 \mathrm{I}$ \\
\hline 9 & $52 \div 25$ & $2.5 I$ & 29 & $97^{-25}$ & $I .50 I$ \\
\hline 10 & 545 & $\because 88$ & 30 & 995 & I'93 \\
\hline $\mathrm{II}$ & $5^{6 \cdot 75}$ & $34 I$ & $3^{I}$ & 10175 & $I * 2 I$ \\
\hline 12 & $59^{\circ}$ & 38 & 32 & $10.4^{\circ}$ & $I \cdot I 2 I$ \\
\hline 13 & $61 \cdot 25$ & 44 & 33 & $105 \cdot 25$ & $2 \cdot 23$ \\
\hline 14 & $63 \cdot 5$ & $30 I$ & 34 & 108.5 & $240 I$ \\
\hline 15 & $65 \div 5$ & $\because 55$ & 35 & 110.75 & 2.68 \\
\hline 16 & $68^{\circ}$ & .61 & 36 & $\operatorname{II} 3^{\circ}$ & $2.80 I$ \\
\hline 17 & 70.25 & $\cdot 69 I$ & 37 & $115 \cdot 25$ & $3 \cdot 20$ \\
\hline 38 & $72: 5$ & $\cdot 76$ & 38 & 117.5 & \\
\hline I9 & 74.75 & $\cdot S_{+} I$ & 39 & $119: 75$ & 340 \\
\hline 20 & $77^{\circ}$ & 90 & 40 & 122 & $3 \cdot 64$ \\
\hline & & & 80 & $212^{\circ}$ & $28^{\circ}$ \\
\hline
\end{tabular}

- The Paris cubic inch $=\mathrm{x} \cdot 2 \mathrm{x}$ Englin. Now the Entih cubic inch of mercury when its fpecific gravity is $1_{3} .6$ weighs 3443.2 Lnglifh grains: therefore the Paris inch weighs 4586 Englith grains, and $\tau$-Ioth of this inch $=45 \$ 6$ grains $:$ and $1--60$ oth of this inch 41.86 grains. 
Note.- $1^{\circ}$. Moft of the interpolations from the 88 th demree to the I 22nd I have myfelf inferted, as thofe calculated by Schmidt erred too widely by his own account.-Gren's Phyf. Jour. iv. 273.

2do. Mr. Pictet has alfo made a fet of curious experiments on the elafticity of pure vapour in low temperatures. E/fais de Pbyjique, p. 557 . He found that a grain of warm water in vacun evaporates in forty minutes in the temperature of $38^{\circ} \mathrm{Fahr}$, under a receiver containing $145^{2}$ Englih cubic inches *, but that it did not diffufe itfelf equally in leis than fix hours, and then raifed the hygrometer from $17^{\circ}$ to $60^{\circ}$, that is $43^{\circ}$; and during this whole time the cold under the receiver was conftantly decreafing, though flowly; which decreafe undoubtedly contributed to the diffufion of the vapour.

Mr. Schmidt has alfo made a feries of experiments upon the dilatability of air, made as $d r y$ as pofitible by expofure to hot tartarin-an object of great importance, that had never before been examined. This table I bere infert, converting Reaumur's degrees into thofe of Fahr. and adding from his formula the degrees he omitted.

\begin{tabular}{|c|c|c|c|c|c|}
\hline Reau.) & Fahren. & $\begin{array}{l}\text { Expanfion } \text { or }^{\circ} \\
\text { one inch at } 32^{\circ} \text {. }\end{array}$ & Redu. & Fairen. & $\begin{array}{l}\text { Expention of } \\
\text { one inch at } 32^{\circ} \text {. }\end{array}$ \\
\hline \multirow[t]{3}{*}{1} & $34^{\circ} 25^{\circ}$ & .0044675 & & $79^{\circ} 25^{\circ}$ & $.093^{8175}$ \\
\hline & $3^{6} 5$ & $.008935^{\circ}$ & & $8 r \cdot 5$ & $\cdot 098285^{\circ}$ \\
\hline & $38 \cdot 7.5$ & .0134025 & & $83 \cdot 75$ & $\cdot 1027525$ \\
\hline \multirow[t]{4}{*}{4} & $4 I^{\circ}$ & .0178700 & 24 & $86^{\circ}$ & 1072200 \\
\hline & $43 \cdot 25$ & .0223375 & & $88 \cdot 25$ & $\cdot 1116875$ \\
\hline & 4.55 & .0268050 & & 90.5 & $.1 \times 16155$ \\
\hline & $47^{\prime} 75$ & .0312726 & & $9^{2 \cdot 75}$ & - 1206225 \\
\hline \multirow[t]{4}{*}{8} & $5^{\circ}$ & .035740 & 28 & $95^{\circ}$ & $\cdot 1250909$ \\
\hline & $5^{2 \cdot 25}$ & .0402075 & & $97^{\prime 25}$ & $\cdot 129.5557$ \\
\hline & 545 & .0446750 & & $99^{\circ} 5$ & $\cdot 1340250$ \\
\hline & $5^{6} 75$ & .0491425 & & $101 \cdot 75$ & $\cdot 1384925$ \\
\hline \multirow[t]{4}{*}{12} & $59^{\circ}$ & -0536100 & $3^{2}$ & $104^{\circ}$ & - 1429600 \\
\hline & $61 \cdot 25$ & .0580775 & & $105 \cdot 25$ & $\cdot{ }^{\prime} 474275$ \\
\hline & $63 * 5$ & .0625450 & & $108 \cdot 5$ & 1518950 \\
\hline & $65 \% 75$ & $\cdot c 670125$ & & 110.75 & $\cdot 1563625$ \\
\hline \multirow[t]{4}{*}{16} & 68. & .0714800 & 36 & $1 \pm 3^{\circ}$ & - 608300 \\
\hline & 70.25 & .0759475 & & $115 \cdot 25$ & $\cdot 1652975$ \\
\hline & 725 & $.080+150$ & & 117.5 & $\cdot 1697650$ \\
\hline & 74.75 & $.08488^{2} 25$ & & 119.75 & 1742825 \\
\hline \multirow[t]{2}{*}{20} & $77^{\circ}$ & .0893500 & 40 & $122^{\circ}$ & - 1787000 \\
\hline & & & & $212^{\circ}$ & 3574000 \\
\hline
\end{tabular}




\section{48}

Note $-1^{\circ}$. Hence we fee that 1000 inches or meafures of dry air at $32^{\circ}$ would become $1004^{\circ} 4675$ at $34^{\circ} 25$ Fahr. and at $50^{\circ}$ would become IOI 7.87 . Hence 1000 meafures of $d r y$ air gain $: 935055$, \&x. by, ea. Is degree of Fahr. above $3^{\circ}$ (or more compendiouny $\cdot 9856$, which is true to two decimal places) or nealy two.

2do. We tee the fource of the difcordant refults of D'amontons, De Luc, Lambert, Schuckburgh, Rov, Berthollet, and Monge, \&c.; for they all operated upon air more imprezrated with various degrees of moifture; befides taking the bolling point at different barometrical heights; in the prefent experiments it was taken at $29.84 \mathrm{I}$ Englifh inches.

3 tio. It appears that the expanfions are as the differences of heat above $3^{2}$, as D'Amontons, Lambert and Schuckburgh alfo noticed; though their experiments, not being made on perfectly dry air, could not be very exact.

[To he continued.]

XXIV. Some Conjectures refpecting the Origin of Stones wobicb bave been obferved to fall from the Clouds. By William Beauford, $A$. M.*

$\mathrm{T}$

$\mathrm{HE}$ falling of ftones from the clouds, a natural phænomenon not generally underftood, is by no means a novel circumftance in the hiftory of nature. Several ftones were obferved to fall from the clouds in Yorkfhire in 1360 , in Bohe$\mathrm{mia}$ and Saxony in 1480 , in Bohemia about 1753 , in Sienna in 1794 , in Portugal in 1796 , in Yorkthire in England in 1795 , and near Benares in the Eaft Indies in 1798 . From an analyfis made of the fe ftones by the French academicians in 1768 , and by the Royal Society of London in 1802 , they are all found fimilar in their component parts to each other, but diffimilar to all bodies found in mines and quarries, being compofed principally of four kinds of fubftances: the firit being in the form of dark grains, compofed of filex, magnefia, iron, and nickel; the fecond, a kind of pyrites; the third, metallic iron; and the fourth, a gray earthy fubftance which ferves as a cement to the others, and with which they were coated. From thefe compofitions the matter feems to be of volcanic origin; yet it is difficult to conceive how ftones of any confiderable magnitude could be thrown at fuch a diftance from any volcano as thofe found in Bohemia, Saxony, and Britain. The neareft volcanos to Britain are thofe of Vefuvius, Etna, and Hecla: a ftone to be thrown into Bri-

* Communicated by the Author.

tain 